J. Natn. Sci. Coun. Sri Lanka 1994 22(3): 253-260

\title{
IN VITRO PROPAGATION OF MUNRONIA PUMILA (BINKOHOMBA)
}

\author{
K. HIRIMBUREGAMA, A.S. SENEVIRATNE, N. GAMAGE and J. GANEGAMA . \\ ARACHCHI \\ Department of Botany, University of Colombo, P.O. Box 1490, Colombo 03.
}

(Received:11 March 1994; accepted: 05 November 1994)

\begin{abstract}
Munronia pumila Wight. (Binkohomba) is a rare endemic medicinal plant found in Sri Lanka. Even though traditional propagation is through seeds, this is not sufficient for commercial scale cultivation due to poor production of seeds and their low viability. Therefore, tissue culture based propagation techniques using mature leaf, petiole, seed and floral parts (petals) as explants were investigated. They were cultured on basic Murashige and Skoog medium with a cytokinin and an auxin at different concentrations. The highest callus formation was observed with mature leaf on $2,4-D(1.1 \mathrm{mg} /)$ and $B A P(0.2 \mathrm{mg} /)$ in complete darkness. Cotyledon and hypocotyl parts of the seed also produced callus. Shoot formation occurred on the callus of cotyledon and hypocotyl in the presence of BAP and NAA. The hypocotyl callus on $5 \mathrm{mg} / \mathrm{BAP}$ and $2 \mathrm{mg} / \mathrm{NAA}$, formed multiple shoots. The study suggests the feasibility of micropropagation of Munronia pumila through callus from hypocotyl and possibly leaves.
\end{abstract}

Key words: Munronia pumila Wight., in vitro culture

\section{INTRODUCTION}

Munronia pumila Wight. (S: binkohomba, family: Meliaceae) is a valuable medicinal plant. In Sri Lanka, it is an endemic species growing in rocky places in the low country such as in Ritigala, Sigiriya, Lunugala and Botale. Binkohomba is a small hardy perennial shrub, with a short stem about $5-10 \mathrm{~cm}$ long with crowded hairy pinnate leaves with long petioles (Fig. 1). The entire Munronia plant is used for medicinal purposes. A decoction of this plant is considered to be an excellent bitter tonic for fever, dysentery and purification of blood. ${ }^{1}$ Sri Lankan flora is rich in plant diversity with about 7106 plant species. Of these, approximately 700 species are used in ayurvedic medicine and many of them are endemic to Sri Lanka. ${ }^{2,3}$ Munronia pumila, is one of these valuable medicinal plants.

Despite the high demand in the local market ( $1 \mathrm{~kg}$ of the dried plant costs about Sri Lankan Rs 1200/=: US\$24), there has been no commercial cultivation of this plant. As a result of over exploitation from the wild, the plant has become rare and if protective measures are not taken, the plant may become extinct in Sri Lanka. Munronia pumila flowers irregularly and only a small percentage (about 12\%) of flowers yield fruits. Therefore, the number of seeds produced from a plant is low (Gamage, unpublished data). Also the seeds are sterile and the percentage of germination is low. Therefore large scale propagation will be difficult through seeds alone. There is no practice of using stem cuttings. Tissue culture techniques have been successfully used commercially to propagate (micropropagate) large number of angiosperms ${ }^{4}$ and may also be used for Munronia pumila. The techniques involved are shoot tip culture, callus cultures, in vitro organogenesis and somatic embryogenesis. $., 5,6$

2,4-D - 2,4 dichloro phenoxy acetic acid, NAA - Naphthalene acetic acid, BAP - Benzyl amino purine 


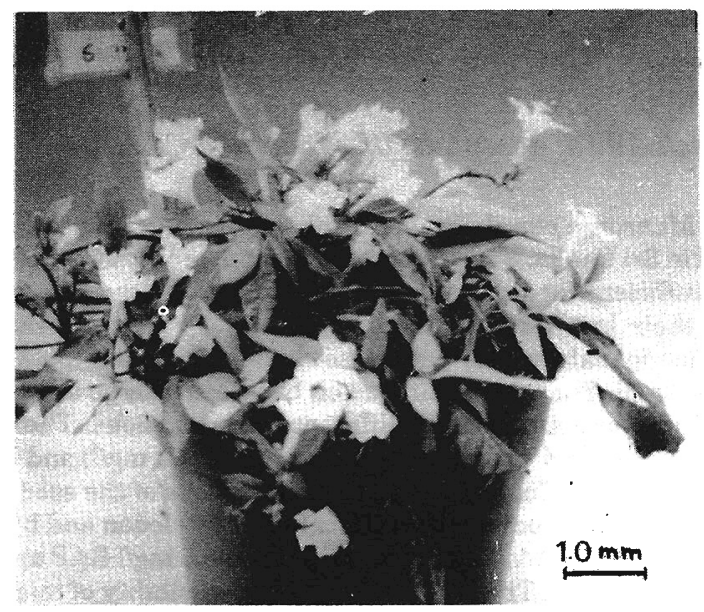

Figure 1: A shrub of Munronia pumila. Wight (Binkohomba).

The objective of the present study was to investigate the feasibility of propagating Munronia pumila through callus cultures. The long term objective is to use this technique as a means of rapid multiplication for reintroduction to the wild and for commercial use.

\section{METHODS AND MATERIALS}

Explant: The explants were taken from greenhouse grown plants. The plants were sprayed with the fungicide Benlate (0.5 g/l, Benomyl. LANKEM $\left.{ }^{\mathrm{TM}}\right)$ 10-12 d, before explants were taken for experiments. The following parts were taken as explants: petiole segments of $1 \mathrm{~cm}$ length, leaf pieces of $1 \mathrm{~cm}^{2}$ from fully grown leaves, mature seed and floral parts (petals).

Surface sterilization: Explants were initially washed well with soap (Sunlight ${ }^{\text {TM}}$ ) and immersed in 50\% (v/v) alcohol for $10 \mathrm{~min}$. They were then kept in $15 \%$ Chlorox (a commercial bleach: $5.2 \% \mathrm{NaOCl}$ ) for $10-15 \mathrm{~min}$. After surface sterilization, explants except seeds, were cut into $0.5 \mathrm{~cm}^{2}$ sizes, under sterile conditions. In seeds, the coat was forced apart before inoculation and the entire seed was inoculated in one tube.

Callus initiation and establishment: Explants were cultured on basic Murashige and Skoog medium ${ }^{7}$ (MS) with $3 \%(w / v)$ sugar and $5 \mathrm{~g} / \mathrm{l}$ agar. This semi-solid basal medium was supplemented with 2,4-D, NAA and BAP in the following combinations for establishment of callus cultures. (i) $2,4-\mathrm{D}(1.1 \mathrm{mg} / \mathrm{l})$ and BAP (0.2 mg/l), (ii) NAA (5 mg/l) and BAP (2 mg/l), (iii) NAA (2 mg/l) and BAP (5 mg/l). 
The culture media ( $20 \mathrm{ml}$ in each glass vessel) were sterilized by autoclaving at $121^{\circ} \mathrm{C}$ and $103.4 \mathrm{KPa}$ for $20 \mathrm{~min}$. After inoculation, the cultures were incubated for a period of 60 days, separately in complete dark and $16 \mathrm{~h}$ of light/day provided through Osram cool fluorescent tubes $\left(4.2 \mathrm{~W} / \mathrm{m}^{2}\right)$. All explants were tested on the three culture media.

Subculturing of the callus: About 50 days after the inoculation of explants, callus cultures which covered two-third of the surface of the explant, were cut into three equal pieces and each piece was transferred onto similar fresh medium and cultured under the same environmental conditions.

Plant regeneration: Calluses produced from explants were tested for plant regeneration. Leaf and cotylédon callus (30 days old) grown on 2,4-D (1.1 mg/) and $\operatorname{BAP}(0.2 \mathrm{mg} / \mathrm{l})$ were inoculated on to the following culture media for shoot regeneration. MS was the basic medium. (i) No growth regulators (plant hormones), (ii) 2,4-D (1.1 mg/l) and BAP $(0.2 \mathrm{mg} / \mathrm{l})$, (iii) BAP $(0.2 \mathrm{mg} / \mathrm{l})$ (iv) $\mathrm{BAP}(1.0 \mathrm{mg} / \mathrm{l}),(\mathrm{v}) \mathrm{BAP}(5.0 \mathrm{mg} / \mathrm{l})$. Cultures were keptin $24 \mathrm{~h}$ light $\left(4.2 \mathrm{~W} / \mathrm{m}^{2}\right)$ supplied by white cool fluorescent tubes. The rate of callus formation on different explants and shoot and root formation over a period of three months were recorded. The mean values with standard deviation were calculated wherever necessary.

Transfer to pots: Plants regenerated from hypocotyl callus were transferred to pots filled with soil: sand at 1:1 ratio. They were transferred when plant height reached $4-5 \mathrm{~cm}$, and were kept in the greenhouse.

\section{RESULTS}

Callus development: Explants behaved differently on culture media with different composition. Callus induction was observed on many explants on many culture compositions (Table 1 ). All the explants, except petals, produced a callus on 2,4-D $(1.1 \mathrm{mg} / \mathrm{l})$ and $\mathrm{BAP}(0.2 \mathrm{mg} / \mathrm{l})$ medium in complete dark, within a relatively short period. Even though a callus was also produced on other culture compositions (Table 1), a longer time was taken for callus initiation. The time of callus initiation on explants varied. From the four types of plant parts tested, the leaf callus was initiated on the 6th day after inoculation. For the other parts, a comparatively longer time was required for callus initiation (Table 1).

The callus was predominantly compact and creamy white (Fig. 2). The leaf callus covered two-third of the surface of the explant in $50 \mathrm{~d}$. This was comparatively lower when compared with the callus growth on other explants. It was possible to maintain the callus by subculturing at every 6 th week on the MS with $1.1 \mathrm{mg} / \mathrm{l} 2,4-\mathrm{D}$ and $0.2 \mathrm{mg} / \mathrm{l} \mathrm{BAP}$. 
Table 1: Response of explants of Munronia on different culture compositions.

\begin{tabular}{lccc}
\hline Explant & \multicolumn{3}{c}{ Time taken for callus initiation (days)* in dark } \\
\cline { 2 - 4 } & $\begin{array}{c}2,4-\mathrm{D}+\mathrm{BAP} \\
(1.1 \mathrm{mg} / \mathrm{l})(0.2 \mathrm{mg} / \mathrm{l})\end{array}$ & $\begin{array}{c}\mathrm{NAA}+\mathrm{BAP} \\
(5 \mathrm{mg} / \mathrm{l})(2 \mathrm{mg} / \mathrm{l})\end{array}$ & $\begin{array}{c}\mathrm{NAA}+\mathrm{BAP} \\
(2 \mathrm{mg} / \mathrm{l})(5 \mathrm{mg} / \mathrm{l})\end{array}$ \\
\hline Leaf & 06 & 25 & - \\
Leaf petiole & 15 & 12 & 20 \\
Hypocotyl & 18 & 14 & 20 \\
Cotyledon & 10 & 15 & 25 \\
Floral parts & - & - & - \\
\hline
\end{tabular}

* Average of 15 replicates given

- No callus development



Figure 2: Callus of Munronia: from hypocotyl part of the seed (50 days in the medium). Illustrates the compact nature of the callus.

Regeneration of plants: Callus of different explants showed a variation in organogenesis on different culture compositions. Organogenesis did not take place on 2,4-D $(1.1 \mathrm{mg} / \mathrm{l})$ and BAP $(0.2 \mathrm{mg} / \mathrm{l})$ medium in dark. But greening of the callus was observed in light. With the removal of both 2,4-D and BAP, green budlike structures were formed on the callus in light. It was also observed that retention of BAP $(0.2 \mathrm{mg} / \mathrm{l})$ in the medium, reduced the formation of bud-like structures. Also, increased levels of BAP in the medium (e.g. $1.0 \mathrm{mg} /, 5.0 \mathrm{mg} / \mathrm{l}$ ), inhibited the formation of bud-like structures. Shoot development from bud- like structures was not observed. 
A good callus developed on 2,4-D and BAP. Callus of seeds cultured on MS with NAA and BAP at two concentrations showed interesting patterns of growth. On $2 \mathrm{mg} / \mathrm{l} \mathrm{NAA}$ and $5 \mathrm{mg} / \mathrm{l}$ BAP, seed germination was followed by callusing at hypocotyl region. Upon transfer to light, within 33 days, many shoot buds were formed on the callus. They grew into small plantlets (Fig. 3). Shoot multiplication was enhanced with successive subculture of the callus every 3 weeks (Table $2 \& 3$ ).

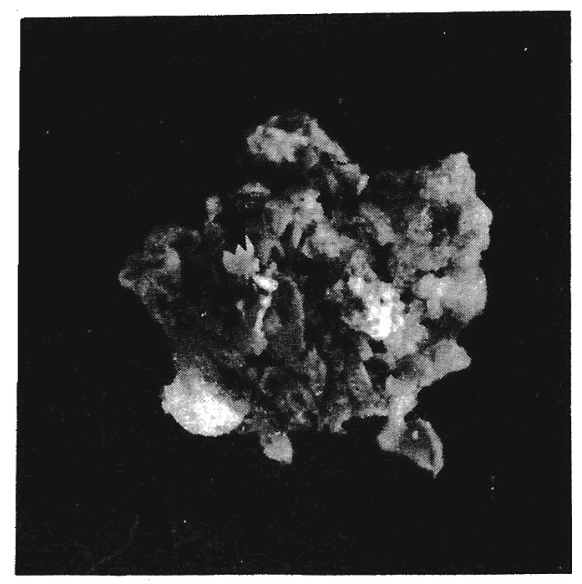

Figure 3: Regeneration of plants from hypocotyl callus of Munronia (on MS with $2 \mathrm{mg} / \mathrm{l}$ NAA and $5 \mathrm{mg} / \mathrm{l}$ BAP, in light).

On $5 \mathrm{mg} / \mathrm{l} \mathrm{NAA}$ and $2 \mathrm{mg} / \mathrm{l} \mathrm{BAP}$ medium, the embryo germinated to a small seedling, followed by callusing on the cotyledon part. Upon transfer to light, within 20 days, tiny shoots were formed on the callus. But, shoot formation was poor than with hypocotyl region (Table 2). However, the leaf callus did not show such a behaviour on this medium.

Table 2: Influence of NAA and BAP on shoot regeneration from seed callus of Munronia.

\begin{tabular}{lccc}
\hline $\begin{array}{l}\text { Culture } \\
\text { medium }\end{array}$ & $\begin{array}{c}\text { Callus } \\
\text { (40d in culture) }\end{array}$ & $\begin{array}{c}\text { No of shoots per vessel } \\
\text { (70d in culture) }\end{array}$ \\
& Cotyledon & Hypocotyl & \\
\hline $\begin{array}{l}\text { NAA }(5 \mathrm{mg} / \mathrm{l}) \\
\mathrm{BAP}(2 \mathrm{mg} / \mathrm{l})\end{array}$ & ++ & - & 2 (on cotyledon) \\
$\begin{array}{l}\mathrm{NAA}(2 \mathrm{mg} / \mathrm{l}) \\
\mathrm{BAP}(5 \mathrm{mg} / \mathrm{l})\end{array}$ & & & \\
\hline
\end{tabular}

- nil, ++ moderately fair, +++ very good callus 
Table 3: Shoot formation from hypocotyl callus and shoot multiplication on NAA (2 mg/l) and BAP (5 mg/l).

\begin{tabular}{ccc}
\hline $\begin{array}{c}\text { Time (days) from } \\
\text { beginning of } \\
\text { regeneration }\end{array}$ & $\begin{array}{c}\text { Subculture } \\
\text { no }\end{array}$ & $\begin{array}{c}\text { No of shoots* } \\
\text { and height }(\mathrm{mm})\end{array}$ \\
\hline 10 & 0 & - \\
33 & 1 & $3.6(0.81), 5.0$ \\
55 & 2 & $8.2(1.35), 6.5$ \\
78 & 3 & $12.2(2.20), 7.0$ \\
\hline
\end{tabular}

* The average number per replicate with the standard error of means within parentheses are given. The average height of shoots $(\mathrm{mm})$ is given after parentheses.

The plants regenerated from hypocotyl (Fig. 4) were transferred to pots (soil:sand at 1:1) in greenhouse. The early vegetative stage of the in vitro propagated plants were true-to-type in their morphology.

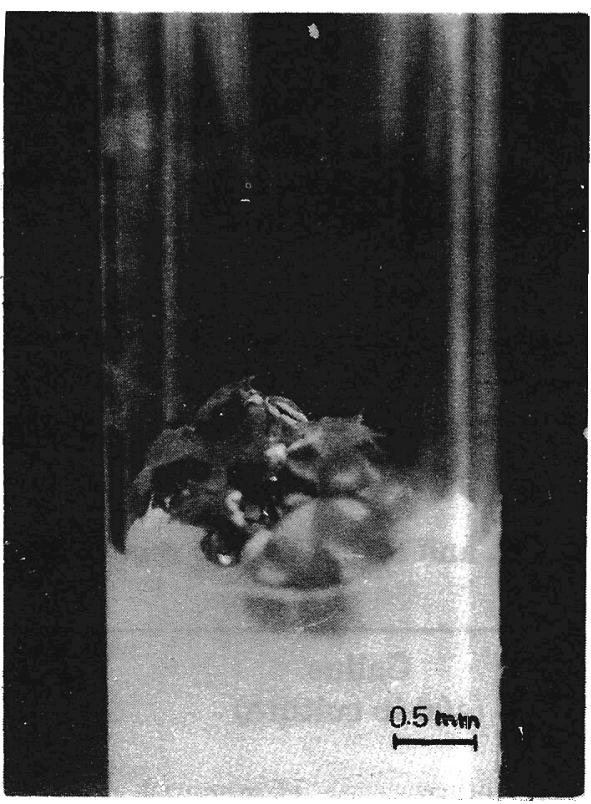

Figure 4: Plants regenerated from the hypocotyl callus: stage before transfer to pots. 


\section{DISCUSSION}

It was observed that in different explants, time of callus initiation varied. This reflects the different response of plant parts in callus formation. Also the results show the influence of plant growth regulators in this diverse behaviour. When considering the differences in tissue composition and the physiological conditions of parts of a plant, diverse behaviour can be expected, especially under in vitro conditions. ${ }^{8,9,10}$

Plant regeneration from callus of different plant parts also varied with physical and chemical conditions. This again highlights the diverse behaviour of plant parts in different environments. Different responses by plant parts under varying chemical environment was also reported in Pericopsis mooniana, in which cotyledon callus had formed shoot buds on $2 \mathrm{mg} / \mathrm{l} \mathrm{BAP}$ and $5 \mathrm{mg} / \mathrm{l}$ NAA while hypocotyl callus had failed to regenerate. ${ }^{11}$ However, in Otacanthus coeruleus, hypocotyl callus had shown shoot proliferation. ${ }^{12}$

The present work reveals the possibility of propagating Munronia pumila Wight. through in vitro callus cultures. The study suggests that the hypocotyl callus of the seed is the best for plant regeneration. Potential also exists for plant regeneration from leaf callus. But more work is needed in this aspect. Experiments are in progress on field testing of the tissue cultured plants and to perfect the methodology.

\section{Acknowledgement}

The financial assistance given by the University of Colombo is gratefully acknowledged.

\section{References}

1. Jayaweera D.M.A. (1982). Medicinal plants (indigenous \& exotic) used in Sri Lanka. Part IV. National Science Council of Sri Lanka, Colombo.

2. Natural Resources of Sri Lanka - Conditions and Trends (1991). Natural Resources, Energy \& Science Authority of Sri Lanka.

3. Abeywickrama B.A. (1985). A survey of the economic plants of Sri Lanka. In Harnessing of Sri Lanka's Natural Resources. (Ed. N. Amerasuriya) pp. 1-11. Vidurava Vol 4 (No 2 \& 3). National Science Council of Sri Lanka.

4. George E.F.\& Sherrington P.D. (1984). Plant propagation by tissue culture. Handbook and directory of commercial laboratories. Exegetics Ltd, Basingstoke, U.K.

5. Pierik R.L.M. (1991). Commercial aspects of micropropagation. In Horticulture- New technologies and applications. (Eds: J. Prakash \& R L M Pierik): pp. 141-153. Kluwer Acad. Publishers, The Netherlands. 
6. Gupta P.K., Timmis R \& Carlson W.C. (1993). Somatic embryogenesis a possible tool for large scale propagation of forestry species. In Advances in Developmental Biology \& Biotechnology of higher plants (Eds:. Woong Young Soh, J.R. Liu \& A. Komamine) pp. 38-70. Proceedings of 1st AsiaPacific Conference in Plant Cell \& Tissue Culture, Korea.

7. Murashige T. \& Skoog F. (1992). A revised medium for rapid growth and bioassay with tobacco tissue cultures. Journal of Plant Physiology 15: 473-497.

8. Price H.J. \& Smith R H. (1977). Cotton. In Handbook of Plant Cell Culture. Crop species 3. (Eds:P.V. Ammirato, D.A. Evans, W.R. Sharp and Y. Yamada): pp. 487-510. Macmillan Publishers, New York.

9. Williams E.G. \& Maheswaran G. (1986). Somatic embryogenesis: factors influencing co-ordinated behaviour of cells as an embryogenic group. Annals of Botany 57: 443-462.

10. Thorpe T.A. (1980). Organogenesis in vitro: structural, physiological and biochemical aspects. In Perspectives in plant cell and tissue culture. International Review of Cytology, supplement 11 A. (Ed. I K Vasil): pp 71-111. Acad. Press, New York

11. Abeyratne W.M., Bandara D.C \& Senanayake Y.D.A. (1991). In vitro propagation of Nadun (Pericopsis mooniana) through callus cultures. In Tropical. Agricultural Research. Vol 2, (Ed: R.O. Thatil) pp. 20-35.

12. Ronse A.C. \& Proft M.P:De. (1992). In vitro propagation of Otacanthus coeruleus Lind. Plant Cell, Tissue \& Organ Culture 30: 243-245. 